\title{
Diurnal Variation in the Responsiveness of Human Subjects to Human Growth Hormone
}

\author{
Daniel Rudman, David Freides, Joseph H. Patterson, and \\ Donna L. GibBas \\ From the Departments of Medicine, Biochemistry, and Pediatrics, Emory \\ University School of Medicine, the Department of Psychology, Emory \\ University, and the Clinical Research Facility, Emory University Hospital, \\ Atlanta, Georgia 30322
}

A в S T R A C T The objective of this study was to compare the responsiveness of human subjects to the anabolic effects of human growth hormone (HGH) administered at 8 a.m. or at 11 p.m. Three doses of $\mathrm{HGH}$ were used: $\mathrm{A}, 0.0168 \mathrm{U} / \mathrm{kg}$ body weight $(\mathrm{BW})^{3 / 4}$ per day; $\mathrm{B}, 0.0532 \mathrm{U} / \mathrm{kg} \mathrm{BW}^{3 / 4}$ per day; $\mathrm{C}, 0.168 \mathrm{U} / \mathrm{kg}$ $\mathrm{BW}^{3 / 4}$ per day. The effect of each dose on daily balances of $\mathrm{N}, \mathrm{P}, \mathrm{Na}$, and $\mathrm{K}$ and on $\mathrm{BW}$ was measured. The subjects were of two groups: (a) seven GH-deficient children, of whom three were deficient in ACTH; and (b) three patients with limb-girdle dystrophy. ACTHdeficient patients in group $(a)$ received exogenous cortisol at 7 a.m. In all 10 subjects, the anabolic effects of dose $\mathrm{C}$, and sometimes of $\mathrm{B}$ and $\mathrm{A}$, administered at 11 p.m. were significantly $(P<0.05)$ greater than when administered at 8 a.m. In these experiments plasma cortisol concentration averaged 3 times greater at 8 a.m. than at 11 p.m.

In the next experiments, exogenous cortisol was administered to the three ACTH-deficient patients at 10 p.m. and the responsiveness to $\mathrm{HGH}$ injected at 11 p.m. vs. 8 a.m. was again compared. Under these conditions, when plasma cortisol concentration averaged 3 times greater at 11 p.m. than at 8 a.m., $\mathrm{HGH}$ injected at 8 a.m. caused significantly greater anabolic responses than $\mathrm{HGH}$ injected at 11 p.m.

These findings indicate that the magnitude of the anabolic response to exogenous $\mathrm{HGH}$ is inversely related to the plasma cortisol concentration at the time of $\mathrm{HGH}$ injection.

Received for publication 5 September 1972 and in revised form 19 December 1972.

\section{INTRODUCTION}

The clinical value of human growth hormone (HGH) as a growth-promoting and anabolic agent is limited by variability in the responsiveness of human subjects and by the limited supply of hormone available. In 2-wk metabolic balance studies, normal children and adults show little or no anabolic response to doses up to 0.15 $\mathrm{U} / \mathrm{kg}$ body weight $(\mathrm{BW})^{3 / 4}$ but generally respond to 0.5 $\mathrm{U} / \mathrm{kg} \mathrm{BW} \mathrm{BW}^{3 / 4}(1-8)$. Daily injection of about $0.05-0.15$ $\mathrm{U} / \mathrm{kg} \mathrm{BW} \mathrm{BW}^{3 / 4}$ (the usual dose in long-term treatment of growth retardation) in short children with normal endogenous GH generally does not accelerate growth (9, 10). GH deficient children are more responsive; doses between 0.015 and $0.15 \mathrm{U} / \mathrm{kg} \mathrm{BW}^{3 / 4}$ usually elicit an acute anabolic response (1). Replacement treatment with $\mathrm{HGH}$ at $0.05-0.15 \mathrm{U} / \mathrm{kg} \mathrm{BW} \mathrm{BW}^{3 / 4}$ accelerates growth in these individuals (11-14), although the growth response is variable and sometimes disappointing $(15,16)$. Adult subjects with myotonic and limb-girdle muscular dystrophies also are more sensitive than normals to the anabolic action of $0.015-0.15 \mathrm{U} / \mathrm{kg} \mathrm{BW}^{3 / 4}(1,3)$; the hormone consequently is being evaluated as a possible form of treatment for these types of dystrophy. $\mathrm{HGH}$ at a dose of about $0.5 \mathrm{U} / \mathrm{kg} \mathrm{BW}^{3 / 4}$ has been suggested as pharmacologic treatment for patients after burns $(17,18)$ and for hypoglycemia $(19,20)$.

The use of HGH for either replacement or pharmacologic therapy is severely limited by scarcity of the hormone, and by the high threshold dose required for anabolic or growth-promoting effect in most subjects with normal endogenous GH. For these reasons, any method of amplifying the human response to $\mathrm{HGH}$ will be valuable. 


\section{TABLE I}

Clinical Summaries of the Subjects

\begin{tabular}{|c|c|c|c|c|c|c|c|c|c|c|c|}
\hline $\begin{array}{c}\text { Case } \\
\text { no. }\end{array}$ & Age & Sex & Ht & $\mathrm{Wt}$ & Bone age & Diagnosis & $\begin{array}{l}\text { Duration } \\
\text { since } \\
\text { diagnosis }\end{array}$ & $\begin{array}{l}\text { Pituitary } \\
\text { hormone } \\
\text { deficiencies }\end{array}$ & $\begin{array}{c}\text { Hormone } \\
\text { replacement } \\
\text { treatment }\end{array}$ & $\begin{array}{l}\text { Muscle } \\
\text { score } \\
(31)^{*}\end{array}$ & $\begin{array}{c}\text { Functional } \\
\text { level } \\
(32)\end{array}$ \\
\hline & $y r$ & & $\mathrm{~cm}$ & $k g$ & $y r$ & & $y r$ & & & & \\
\hline 1 & 11 & $\mathbf{M}$ & 120 & 30 & 5 & Isolated GH deficiency & 6 & GH & None & 0 & 1 \\
\hline 2 & 15 & M & 124 & 28 & 7 & Isolated GH deficiency & 2 & GH & None & 0 & 1 \\
\hline 3 & 17 & $\mathrm{~F}$ & 134 & 37 & 14 & $\begin{array}{l}\text { Deficiency of GH and } \\
\text { gonadotropins } \\
\text { (idiopathic) }\end{array}$ & 4 & $\mathrm{GH}, \mathrm{FSH}, \mathrm{LH}$ & None & 0 & 1 \\
\hline 4 & 16 & $\mathrm{~F}$ & 151 & 48 & 16 & $\begin{array}{l}\text { Panhypopituitarism } \\
\text { after excision of } \\
\text { craniopharyngioma }\end{array}$ & 4 & $\begin{array}{l}\text { GH, TSH, } \\
\text { ACTH, FSH, } \\
\text { LH, ADH }\end{array}$ & $\begin{array}{c}\text { Thyroxine, } \\
\text { cortisol, } \\
\text { pitressin }\end{array}$ & 0 & 1 \\
\hline 5 & 17 & $\mathrm{~F}$ & 160 & 75 & 13 & $\begin{array}{l}\text { Panhypopituitarism } \\
\text { after excision of } \\
\text { craniopharyngioma }\end{array}$ & 6 & $\begin{array}{l}\text { GH, TSH, } \\
\text { ACTH, FSH, } \\
\text { LH, ADH }\end{array}$ & $\begin{array}{c}\text { Thyroxine, } \\
\text { cortisol, } \\
\text { pitressin }\end{array}$ & 0 & 1 \\
\hline 6 & 14 & $\mathrm{M}$ & 150 & 62 & 11 & $\begin{array}{l}\text { Panhypopituitarism } \\
\text { after excision of } \\
\text { craniopharyngioma }\end{array}$ & 9 & $\begin{array}{l}\text { GH, TSH, } \\
\text { ACTH, FSH, } \\
\text { LH, ADH }\end{array}$ & $\begin{array}{c}\text { Thyroxine, } \\
\text { cortisol, } \\
\text { pitressin }\end{array}$ & 0 & 1 \\
\hline 7 & 19 & $\mathrm{~F}$ & 140 & 37 & 13 & $\begin{array}{l}\text { Panhypopituitarism } \\
\text { after excision of } \\
\text { craniopharyngioma }\end{array}$ & 11 & $\begin{array}{l}\text { GH, TSH, } \\
\text { ACTH, FSH, } \\
\text { LH, ADH }\end{array}$ & $\begin{array}{c}\text { Thyroxine, } \\
\text { cortisol, } \\
\text { pitressin }\end{array}$ & 0 & 1 \\
\hline 8 & 51 & $\mathbf{M}$ & 165 & 71 & Adult & Limb-girdle dystrophy & 31 & None & None & 310 & 4 \\
\hline 9 & 34 & $\mathbf{M}$ & 181 & 51 & Adult & Limb-girdle dystrophy & 13 & None & None & 235 & 3 \\
\hline 10 & 29 & $\mathbf{M}$ & 179 & 78 & Adult & Limb-girdle dystrophy & 11 & None & None & 95 & 2 \\
\hline
\end{tabular}

* Total loss of strength in all 68 muscles tested would give a score of 440 , total normality a score of 0 .

One possibility involves timing of the HGH injection. After the exogenous hormone is injected intravenously in human subjects, its rate of disappearance from the serum approximates a single exponential function over the period 0-90 min, with a half-time of $15-50 \mathrm{~min}$ (21, 22). The duration of effect of a single dose, however, is not known. Najjar and Blizzard (16) have compared the growth-promoting effect of $(a)$ a specific dose of $\mathrm{HGH}$ once a day, (b) twice the dose every other day, and $(c)$ half the dose twice a day, on the rate of growth of pituitary dwarfs. The three schedules were said to be generally equipotent, but data supporting this conclusion were not presented. In the hypophysectomized rat, however, injection of half a specified dose of bovine $\mathrm{GH}$ twice a day gave a greater response than injection of the entire dose once a day in the morning (23).

Another aspect of timing concerns the diurnal rhythm of endogenous HGH, which is secreted by the adenohypophysis largely during the first $2 \mathrm{~h}$ of sleep (24). Furthermore, secretion of cortisol, which antagonizes the anabolic effect of $\mathrm{HGH}(25,26)$, shows the opposite rhythm. Although this hormone is secreted episodically (27), its plasma concentration is greater during the day than at night $(28,29)$. Further, this concentration falls to a minimum during slow-wave sleep (27), when plasma growth hormone concentration rises to a maximum (24). These relationships suggest that the anabolic effectiveness of exogenous HGH may be influenced by the time of day at which it is injected and also by timing of any exogenous glucocorticoid which the patient may be receiving.

The initial objective of the present study was to compare the responsiveness of human subjects to the anabolic effects of $\mathrm{HGH}$ injected at $8 \mathrm{a} . \mathrm{m}$. or 11 p.m. Two types of patient were studied: ${ }^{1}(a)$ growth-hormonedeficient subjects, age 7-18; $(b)$ adult patients with limb-girdle dystrophy. As indicators of response, we measured increments in daily balances of $\mathrm{N}, \mathrm{P}, \mathrm{Na}$, and $\mathrm{K}$ and in body weight (BW). The results of these ex-

\footnotetext{
${ }^{1}$ Previous studies $(1,3)$ have shown that both categories are 5-10 times more responsive to the anabolic effects of $\mathrm{HGH}$ than normal individuals. The minimal effective dose for the anabolic effect of $\mathrm{HGH}$ in normals is $0.168-0.532$ $\mathrm{U} / \mathrm{kg} \mathrm{BW}^{3 / 4}$ daily, compared to $0.0532-0.168 \mathrm{U} / \mathrm{kg} \mathrm{BW}^{3 / 4}$ for the patients cited. The supply of $\mathrm{HGH}$ available to us was not sufficient to conduct these experiments in normals.
} 
TABLE II

Effect of Altering Times of Administration of HGH and of Cortisol upon the Anabolic Effect of HGH

\begin{tabular}{|c|c|c|c|c|c|c|c|c|c|c|c|}
\hline \multirow{2}{*}{$\begin{array}{l}\text { Case } \\
\text { no. }\end{array}$} & \multirow{2}{*}{$\begin{array}{l}\text { Exp } \\
\text { no. }\end{array}$} & \multirow{2}{*}{$\begin{array}{l}\text { Series } \\
\text { no. }\end{array}$} & \multirow{2}{*}{$\begin{array}{c}\text { HGH } \\
\text { dosage } \\
\text { schedule }\end{array}$} & \multirow{2}{*}{$\begin{array}{l}\text { Cortisol } \\
\text { dosage } \\
\text { schedule }\end{array}$} & \multicolumn{3}{|c|}{$\begin{array}{l}\text { Plasma cortisol } \\
\text { concentration* }\end{array}$} & \multicolumn{4}{|c|}{ Response to HGH (per kg BW $3 / 4 \times 10^{-1}$ ) } \\
\hline & & & & & 8 a.m. & 3 p.m. & 11 p.m. & $\Delta \mathrm{N}$ & $\Delta \mathbf{P}$ & $\Delta \mathrm{Na}$ & $\Delta \mathbf{K}$ \\
\hline & & & & & \multicolumn{3}{|c|}{$\mu \mathrm{g} / 100 \mathrm{ml}$} & $g$ & $g$ & $m e q$ & $m e q$ \\
\hline \multirow{9}{*}{1} & 1 & I & A, 8 a.m. & None & 23 & 15 & 4 & $0.2 \pm 0.1$ & $-0.03 \pm 1.5$ & $3.3 \pm 1.5$ & $-1.5 \pm 0.7$ \\
\hline & 2 & I & A, 11 p.m. & None & 15 & 11 & 8 & $0.9 \pm 0.1 \ddagger$ & $0.10 \pm 0.02 \ddagger$ & $8.3 \pm 2.1 \ddagger$ & $5.1 \pm 1.1 \ddagger$ \\
\hline & 3 & I & $\mathrm{B}, 8$ a.m. & None & 21 & 17 & 9 & $0.7 \pm 0.1 \ddagger$ & $0.03 \pm 0.02$ & $5.7 \pm 2.1$ & $3.2 \pm 2.1$ \\
\hline & 4 & I & B, 11 p.m. & None & 18 & 9 & 4 & $1.4 \pm 0.2 \ddagger$ & $0.16 \pm 0.03 \ddagger$ & $12.4 \pm 3.0 \ddagger$ & $7.4 \pm 1.8 \ddagger$ \\
\hline & 5 & I & C, 8 a.m. & None & 26 & 15 & 5 & $1.4 \pm 0.2 \ddagger$ & $0.08 \pm 0.04$ & $7.5 \pm 1.9 \ddagger$ & $3.9 \pm 2.0 \ddagger$ \\
\hline & 6 & I & C, 11 p.m. & None & 20 & 17 & 10 & $2.1 \pm 0.3 \ddagger$ & $0.17 \pm 0.02 \ddagger$ & $13.6 \pm 3.4 \ddagger$ & $8.7 \pm 2.1 \ddagger$ \\
\hline & \multirow{3}{*}{\multicolumn{4}{|c|}{$\begin{array}{r}P \text { values } \exp 2 \text { vs. } \exp 1 \\
\exp 4 \text { vs. } \exp 3 \\
\exp 6 \text { vs. } \exp 5\end{array}$}} & & & & $<0.05$ & $<0.001$ & NS & $<0.01$ \\
\hline & & & & & & & & $<0.05$ & $<0.001$ & NS & NS \\
\hline & & & & & & & & $<0.05$ & $<0.005$ & NS & $<0.05$ \\
\hline \multirow[t]{9}{*}{2} & 1 & I & A, 11 p.m. & None & 19 & 14 & 4 & $0.2 \pm 0.1$ & $-0.05 \pm 0.03$ & $4.2 \pm 2.1$ & $-3.2 \pm 1.9$ \\
\hline & 2 & I & A, 8 a.m. & None & 26 & 18 & 8 & $0.1 \pm 0.1$ & $0.03 \pm 0.02$ & $6.5 \pm 3.1$ & $3.1 \pm 1.9$ \\
\hline & 3 & I & B, 11 p.m. & None & 20 & 12 & 7 & $1.3 \pm 0.2 \ddagger$ & $0.09 \pm 0.04$ & $11.7 \pm 2.3 \ddagger$ & $6.4 \pm 1.8 \ddagger$ \\
\hline & 4 & I & B, 8 a.m. & None & 17 & 15 & 5 & $0.4 \pm 0.2$ & $0.02 \pm 0.02$ & $7.0 \pm 3.1$ & $3.3 \pm 1.1 \ddagger$ \\
\hline & 5 & I & C, 11 p.m. & None & 18 & 21 & 10 & $1.7 \pm 0.2 \ddagger$ & $0.18 \pm 0.03 \ddagger$ & $16.5 \pm 2.9 \ddagger$ & $9.5 \pm 1.9 \ddagger$ \\
\hline & 6 & I & $\mathrm{C}, 8$ a.m. & None & 24 & 18 & 7 & $0.7 \pm 0.2 \ddagger$ & $0.07 \pm 0.02 \ddagger$ & $7.4 \pm 3.5$ & $4.4 \pm 1.7 \ddagger$ \\
\hline & \multirow{3}{*}{\multicolumn{4}{|c|}{$\begin{array}{r}P \text { values } \exp 2 \text { vs. } \exp 1 \\
\exp 4 \text { vs. } \exp 3 \\
\exp 6 \text { vs. } \exp 5\end{array}$}} & & & & NS & $<0.01$ & NS & $<0.01$ \\
\hline & & & & & & & & $<0.01$ & $<0.02$ & NS & NS \\
\hline & & & & & & & & $<0.005$ & $<0.001$ & NS & $<0.05$ \\
\hline \multirow[t]{8}{*}{3} & 1 & I & A, 8 a.m. & None & 19 & 15 & 3 & $-0.3 \pm 0.2$ & $0.03 \pm 0.03$ & $3.1 \pm 1.9$ & $2.4 \pm 1.5$ \\
\hline & 2 & I & A, 11 p.m. & None & 16 & 13 & 8 & $0.2 \pm 0.1$ & $-0.03 \pm 0.02$ & $-4.5 \pm 2.8$ & $2.1 \pm 1.1$ \\
\hline & 3 & I & B, 11 p.m. & None & 27 & 15 & 5 & $0.8 \pm 0.1$ & $0.07 \pm 0.01$ & $7.5 \pm 3.9$ & $5.1 \pm 2.7$ \\
\hline & 4 & I & B, 8 a.m. & None & 21 & 18 & 7 & $1.0 \pm 0.2$ & $0.08 \pm 0.02$ & $6.4 \pm 3.2$ & $6.3 \pm 1.8$ \\
\hline & 5 & I & C, 8 a.m. & None & 15 & 15 & 8 & $1.0 \pm 0.1$ & $0.11 \pm 0.03$ & $7.1 \pm 3.5$ & $4.6 \pm 1.1$ \\
\hline & 6 & I & C, 11 p.m. & None & 20 & 11 & 4 & $2.0 \pm 0.3$ & $0.24 \pm 0.06$ & $18.3 \pm 3.6$ & $9.1 \pm 1.9$ \\
\hline & \multirow{2}{*}{\multicolumn{4}{|c|}{$\begin{array}{r}P \text { values } \exp 2 \text { vs. } \exp 1 \\
\exp 4 \text { vs. } \exp 3 \\
\exp 6 \text { vs. } \exp 5\end{array}$}} & & & & $\begin{array}{l}\text { NS } \\
\text { NS }\end{array}$ & $\begin{array}{l}\text { NS } \\
\text { NS }\end{array}$ & $\begin{array}{l}\text { NS } \\
\text { NS }\end{array}$ & $\begin{array}{l}\text { NS } \\
\text { NS }\end{array}$ \\
\hline & & & & & & & & $<0.005$ & $<0.001$ & $<0.05$ & NS \\
\hline \multirow[t]{6}{*}{4} & 1 & I & C, 8 a.m. & $20 \mathrm{mg}, 7$ a.m. & 25 & 6 & 2 & $1.1 \pm 0.1 \ddagger$ & $0.09 \pm 0.4$ & $7.5 \pm 3.8$ & $5.1 \pm 1.1 \ddagger$ \\
\hline & 2 & I & C, 11 p.m. & $20 \mathrm{mg}, 7$ a.m. & 19 & 8 & 3 & $1.9 \pm 0.2 \ddagger$ & $0.24 \pm 0.05 \ddagger$ & $14.4 \pm 2.7 \ddagger$ & $9.3 \pm 2.0 \ddagger$ \\
\hline & 3 & II & C, 8 a.m. & $20 \mathrm{mg}, 7$ a.m. & 7 & 3 & 28 & $1.5 \pm 0.2 \ddagger$ & $0.18 \pm 0.05 \ddagger$ & $9.1 \pm 2.1 \ddagger$ & $8.7 \pm 1.9 \ddagger$ \\
\hline & 4 & II & C, 11 p.m. & $20 \mathrm{mg}, 10$ p.m. & 9 & 2 & 21 & $0.8 \pm 0.2 \ddagger$ & $0.09 \pm 0.03$ & $8.7 \pm 2.4 \ddagger$ & $3.6 \pm 1.9$ \\
\hline & \multirow{2}{*}{\multicolumn{4}{|c|}{$\begin{array}{r}P \text { values } \exp 2 \text { vs. } \exp 1 \\
\exp 4 \text { vs. } \exp 3\end{array}$}} & & & & $<0.01$ & $<0.001$ & $<0.10$ & $<0.05$ \\
\hline & & & & & & & & $<0.05$ & $<0.005$ & NS & $<0.05$ \\
\hline \multirow[t]{5}{*}{5} & 1 & $\begin{array}{l}\text { I } \\
\text { I }\end{array}$ & C, 8 a.m. & $25 \mathrm{mg}, 7$ a.m. & 29 & 11 & 3 & $0.9 \pm 0.1 \ddagger$ & $0.09 \pm 0.04$ & $7.6 \pm 3.7$ & $5.8 \pm 1.9 \ddagger$ \\
\hline & 2 & III & C, 11 p.m. & $25 \mathrm{mg}, 7$ a.m. & 19 & 8 & 5 & $1.6 \pm 0.2 \ddagger$ & $0.12 \pm 0.03 \ddagger$ & $11.9 \pm 3.1 \ddagger$ & $8.3 \pm 2.3 \ddagger$ \\
\hline & 3 & III & C, 11 p.m. & $25 \mathrm{mg}, 10$ p.m. & 24 & 13 & 4 & $0.9 \pm 0.1 \ddagger$ & $0.10 \pm 0.03 \ddagger$ & $8.4 \pm 2.8 \ddagger$ & $4.6 \pm 2.8$ \\
\hline & \multirow{2}{*}{\multicolumn{4}{|c|}{$\begin{array}{r}P \text { values } \exp 2 \text { vs. } \exp 1 \\
\exp 3 \text { vs. } \exp 2\end{array}$}} & & & & $<0.05$ & NS & NS & NS \\
\hline & & & & & & & & $<0.05$ & NS & NS & NS \\
\hline \multirow[t]{6}{*}{6} & 1 & I & C, 11 p.m. & $20 \mathrm{mg}, 7$ a.m. & 19 & 8 & 2 & $1.6 \pm 0.2 \ddagger$ & $0.11 \pm 0.03 \ddagger$ & $14.5 \pm 3.3 \ddagger$ & $7.9 \pm 1.7 \ddagger$ \\
\hline & $\begin{array}{l}2 \\
3\end{array}$ & I & $\begin{array}{l}\text { C, } 8 \text { a.m. } \\
\text { C, } 8 \text { a.m. }\end{array}$ & $\begin{array}{l}20 \mathrm{mg}, 7 \text { a.m. } \\
20 \mathrm{mg}, 10 \text { p.m. }\end{array}$ & $\begin{array}{r}27 \\
8\end{array}$ & $\begin{array}{l}6 \\
3\end{array}$ & $\begin{array}{r}4 \\
26\end{array}$ & $\begin{array}{l}1.0 \pm 0.2 \ddagger \\
1.3 \pm 0.1 \ddagger\end{array}$ & $\begin{array}{l}0.05 \pm 0.03 \\
0.15 \pm 0.04 \ddagger\end{array}$ & $\begin{array}{c}8.1 \pm 3.9 \\
11.6 \pm 3.0 \ddagger\end{array}$ & $\begin{array}{l}6.0 \pm 3.1 \ddagger \\
8.5 \pm 2.5 \ddagger\end{array}$ \\
\hline & 4 & II & C, 11 p.m. & $20 \mathrm{mg}, 10$ p.m. & 4 & 2 & 20 & $0.6 \pm 0.2$ & $0.03 \pm 0.02$ & $5.3 \pm 3.1$ & $4.6 \pm 2.3$ \\
\hline & \multirow{3}{*}{\multicolumn{4}{|c|}{$\begin{array}{r}P \text { values } \exp 2 \text { vs. } \exp 1 \\
\exp 3 \text { vs. } \exp 2 \\
\exp 4 \text { vs. } \exp 3\end{array}$}} & & & & NS & $<0.05$ & NS & NS \\
\hline & & & & & & & & NS & $<0.005$ & NS & NS \\
\hline & & & & & & & & $<0.05$ & $<0.001$ & NS & NS \\
\hline
\end{tabular}


TABLE II-(Continued)

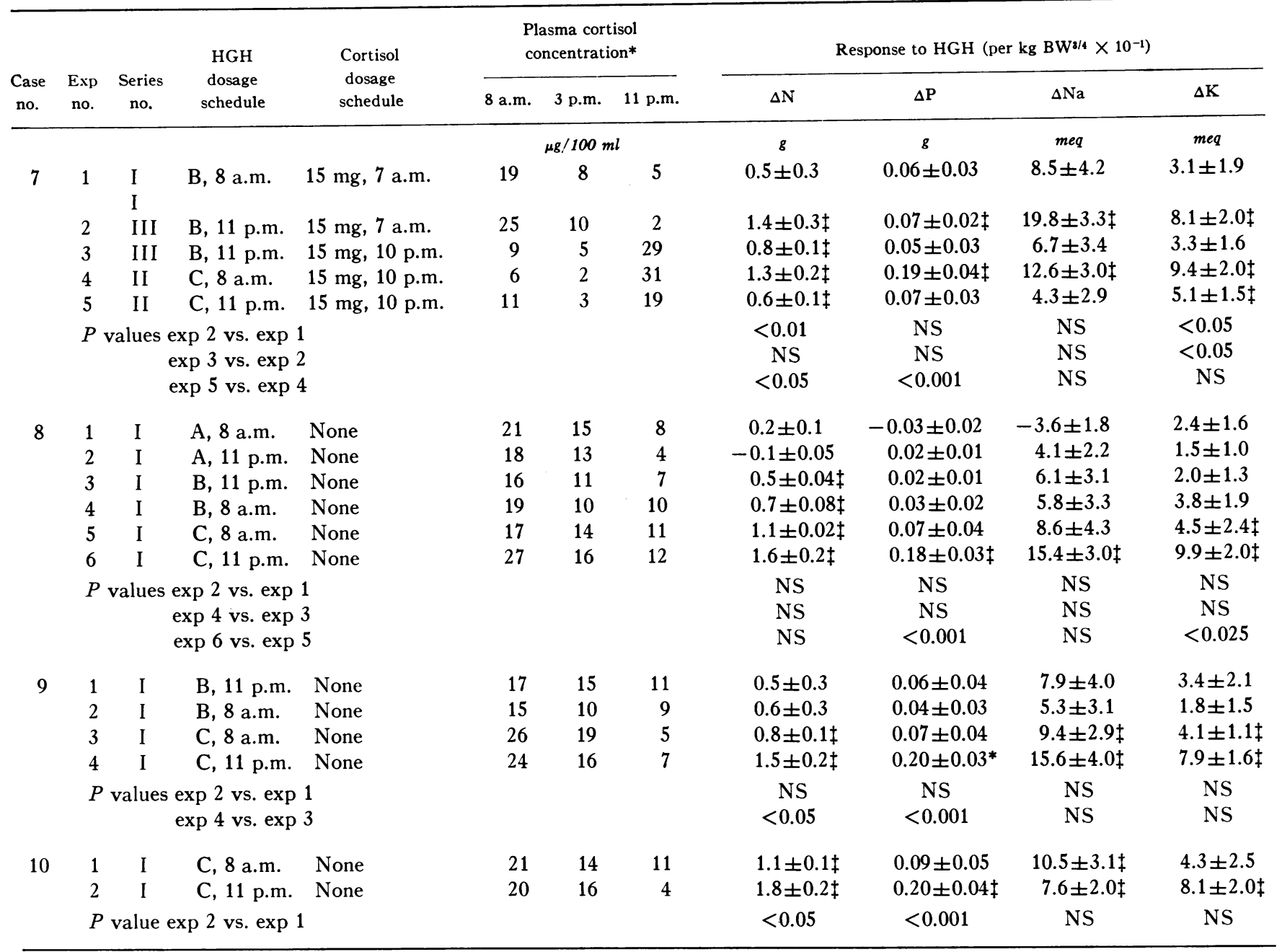

Experiments for which a $P$ value was calculated were conducted within the same 90 day period. Response is expressed as average daily $\Delta \pm \mathrm{SE}(n=7)$.

* Average $\pm \operatorname{SE}(n=3)$.

$\ddagger$ Statistically significant response to HGH $(P<0.05$ for the difference in daily elemental balance during experimental and control periods of the metabolic balance study). NS signifies $P>0.05$.

periments led to additional studies in hypophysectomized patients receiving exogenous cortisol, wherein the time of injection of $\mathrm{HGH}$ was held constant and the time of cortisol administration varied.

\section{METHODS}

The clinical data of the subjects are summarized in Table I. (a) Seven children, age 11-19, deficient in $\mathrm{HGH}$. In four the pituitary gland had been removed because of tumor. In these four, and in an additional one with nonneoplastic pituitary disease, deficiency of $\mathrm{HGH}$ was accompanied by deficiency of one or more other pituitary hormones. Criteria for establishing deficiency of $\mathrm{HGH}$, adrenocorticotropin, thyroid-stimulating hormone, gonadotropins, or antidiuretic hormone were as described before (1). Replacement doses for these deficiencies were: cortisol, 15-25 mg daily, administered at either 7 a.m. or 10 p.m. as specified; thyroxine, $0.2-0.3 \mathrm{mg}$ daily given at $8 \mathrm{a.m}$.; pitressin tannate in oil, 3-5 $\mathrm{U}$ intramuscularly at $24-$ to $72-\mathrm{h}$ intervals. During the time of this study, plasma thyroxine iodine concentration was $3.5-6.4 \mu \mathrm{g} / 100 \mathrm{ml}$; urine volume did not exceed 1500 $\mathrm{ml} /$ day. Plasma cortisol concentrations are given in Table II. (b) Three patients with limb-girdle dystrophy. The criteria for this diagnosis are given in reference 3 .

The effect of $\mathrm{HGH}$ at three doses $\left(0.0168 \mathrm{U} / \mathrm{kg} \mathrm{BW}^{3 / 4}\right.$, dose A; $0.0532 \mathrm{U} / \mathrm{kg} \mathrm{BW}^{3 / 4}$, dose $\mathrm{B} ; 0.168 \mathrm{U} / \mathrm{kg} \mathrm{BW}^{3 / 4}$, dose $\mathrm{C})^{2}$ on balances of $\mathrm{N}, \mathrm{P}, \mathrm{Na}$, and $\mathrm{K}$ and on $\mathrm{BW}$ was measured as described before (1-3). The measurement of these responses to a given dose of $\mathrm{HGH}$ required a 17

${ }^{2}$ For a $50 \mathrm{~kg}$ subject these doses represent $0.32,1.00$, and $3.2 \mathrm{U} /$ day, respectively. 
TABLE III

Effect of Separating (a) Time of Injection of HGH from (b) Time of Maximal Plasma Cortisol Concentration by 8-12 $h$ upon the Metabolic Response to $H G H$

\begin{tabular}{|c|c|c|c|c|c|c|c|c|c|c|c|c|c|c|}
\hline \multirow[b]{2}{*}{ Series } & \multirow[b]{2}{*}{ HGH dose } & \multirow{2}{*}{$\begin{array}{l}\text { Number } \\
\text { comparisons }\end{array}$} & \multicolumn{3}{|c|}{$\Delta \mathrm{N}$} & \multicolumn{3}{|c|}{$\Delta \mathbf{P}$} & \multicolumn{3}{|c|}{$\Delta \mathrm{Na}$} & \multicolumn{3}{|c|}{$\Delta \mathrm{K}$} \\
\hline & & & 0 & $\uparrow$ & $\downarrow$ & 0 & $\uparrow$ & $\downarrow$ & 0 & $\uparrow$ & $\downarrow$ & 0 & $\uparrow$ & $\downarrow$ \\
\hline \multirow[t]{3}{*}{ I } & Dose A & 4 & 3 & 1 & 0 & 2 & 2 & 0 & 4 & 0 & 0 & 2 & 2 & 0 \\
\hline & Dose B & 6 & 3 & 3 & 0 & 4 & 2 & 0 & 6 & 0 & 0 & 5 & 1 & 0 \\
\hline & Dose C & 9 & 2 & 7 & 0 & 1 & 8 & 0 & 8 & 1 & 0 & 6 & 3 & 0 \\
\hline II & Dose C & 3 & 0 & 3 & 0 & 0 & 3 & 0 & 3 & 0 & 0 & 2 & 1 & 0 \\
\hline \multirow[t]{2}{*}{ III } & Dose B & 1 & 1 & 0 & 0 & 1 & 0 & 0 & 1 & 0 & 0 & 0 & 1 & 0 \\
\hline & Dose C & 1 & 0 & 1 & 0 & 1 & 0 & 0 & 1 & 0 & 0 & 1 & 0 & 0 \\
\hline
\end{tabular}

0 signifies the response was not significantly $(P>0.05)$ altered by separating $(a)$ and $(b)$ by $8-12 \mathrm{~h}$.

$\uparrow$ and $\downarrow$ signify the response was significantly $(P<0.05)$ increased or decreased, respectively, by separating $(a)$ and $(b)$ by 8-12 h.

day hospital study : 3 day equilibration period, 7 day control period, 7 day HGH period. During the control period, BW did not change by $>0.03 \mathrm{~kg} / \mathrm{kg} \mathrm{BW} \mathrm{BW}^{3 / 4} \times 10^{-1}$ and average daily balances were within the following ranges per kilogram $\mathrm{BW}^{3 / 4} \times 10^{-1}: \mathrm{N} \pm 0.6 \mathrm{~g}, \mathrm{P} \pm 0.07 \mathrm{~g}, \mathrm{Na} \pm 6.0 \mathrm{meq}$, $\mathrm{K} \pm 2.3$ meq. Responses were calculated as daily increments in elemental balances (average daily balance during 7 day HGH period minus average daily balance during 7 day control period): $\Delta \mathrm{N}$ (grams), $\Delta \mathrm{P}$ (grams), $\Delta \mathrm{Na}$ (milliequivalents, and $\Delta \mathrm{K}$ (milliequivalents).

In each subject, the 17 day experiments were done at 1to 3-mo intervals over a 12 mo period. In these two to six experiments in each subject, the dose and timing of $\mathrm{HGH}$ and (in some hypophysectomized cases) the timing of exogenous cortisol were systematically varied as shown in Table II, in order to determine the relationship between timing of the two hormones and magnitude of anabolic response to each dose of $\mathrm{HGH}$.

\section{RESULTS}

Experimental series $I$ : comparison of $H G H$ at 8 a.m. and 11 p.m., plasma cortisol being maximal" at 8 a.m. In the four hypophysectomized cases (4-7) who received exogenous cortisol, the entire dose was given at 7 a.m. In these four cases, and also in the six other subjects not receiving exogenous cortisol, the effect of $\mathrm{HGH}$ at dose $\mathrm{C}, \mathrm{B}$, and (sometimes) A was compared when the hormone was injected at 8 a.m. and when it was injected at bedtime. The experiments, conducted at $30-$ to 90-day intervals, are listed chronologically in Table II. Average plasma cortisol levels of the patients in all these experiments were highest at 8 a.m., intermediate at 3 p.m., and lowest at 11 p.m.

19 comparisons in all were made: 9 at dose $\mathrm{C}, 6$ at dose $\mathrm{B}$, and 4 at dose $\mathrm{A}$. In no comparison did $\mathrm{HGH}$ at 8 a.m. produce a greater effect than at 11 p.m. (Table III). In 8 comparisons, no significant difference in response was found. In the remaining 11 comparisons,

Among the three times at which plasma cortisol concentration was measured: 8 a.m., 3 p.m., and 11 p.m.
HGH administered at 11 p.m. caused significantly greater anabolic effect at bedtime than $\mathrm{HGH}$ given at 8 a.m. In 7 of 9 comparisons, dose $\mathrm{C}$ administered at 11 p.m. caused a significantly greater response than when given at 8 a.m. For doses $\mathrm{B}$ and $\mathrm{A}$ this relationship was evident in 3 of 6 and in 1 of 4 comparisons, respectively. The greater effect of $\mathrm{HGH}$ injected at 11 p.m. was usually evident in the retentions of $\mathrm{N}$ and $\mathrm{P}$, less often in those of $\mathrm{Na}$ and $\mathrm{K}$. The results of series I are summarized in Tables III and IV.

Experimental series II: comparison of anabolic effect of HGH at 8 a.m. and 11 p.m., plasma cortisol level being maximal ${ }^{s}$ at 11 p.m. In these experiments with three hypophysectomized children, the replacement dose of cortisol was given throughout the equilibration, control, and HGH periods at 10 p.m. HGH was given either at 8 a.m. or at 11 p.m. Six experiments, providing three comparisons, were made. In all three comparisons, dose $C$ at 11 p.m. caused a lesser anabolic effect than at 8 a.m. (Table II, III, and IV).

Experimental series III: effect of changing administration of exogenous cortisol from 7 a.m. to 10 p.m. upon anabolic effect of dose C HGH administered at 11 p.m. Only two comparisons were made. In one comparison, the $\mathrm{N}$ response was significantly enhanced by separating the administration of the two hormones by $8 \mathrm{~h}$; in the other, a significant difference was not apparent.

\section{DISCUSSION}

Experiments of series I show that in patients with normal diurnal rhythm of endogenous cortisol, or in patients receiving exogenous cortisol at 7 a.m., HGH exerts a stronger anabolic action when injected at 11 p.m. than at $8 \mathrm{a} . \mathrm{m}$. The enhancement of bedtime injection is evident both as increased magnitude of response to doses $B$ and $C$ and, in some instances, by lowering of the minimal effective dose from $C$ to $B$ or from $B$ to $A$. 
TABLE IV

Summary of Series I and II

\begin{tabular}{|c|c|c|c|c|c|c|}
\hline & & $\Delta \mathrm{N}$ & $\Delta \mathrm{P}$ & & $\Delta \mathrm{Na}$ & $\Delta \mathrm{K}$ \\
\hline \multicolumn{7}{|c|}{ Series I: plasma cortisol concentration maximal at 8 a.m. } \\
\hline \multirow[t]{3}{*}{ HGH 8 a.m. } & Dose A & $0.1 \pm 0.02$ & $0 \pm 0.02$ & $(4)$ & $2.3 \pm 2.1 \quad(4)$ & $1.6 \pm 1.05$ \\
\hline & Dose B & $0.7 \pm 0.09(6)$ & $0.06 \pm 0.01$ & (6) & $6.5 \pm 0.47(6)$ & $3.6 \pm 0.6 \quad(6)$ \\
\hline & Dose C & $1.0 \pm 0.02$ & $0.08 \pm 0.005$ & (9) & $8.2 \pm 0.37(9)$ & $4.7 \pm 0.25$ \\
\hline \multirow[t]{3}{*}{ HGH 11 p.m. } & Dose A & $0.3 \pm 0.21$ & $0.01 \pm 0.03$ & (4) & $3.0 \pm 2.7 \quad(4)$ & $1.4 \pm 1.7$ \\
\hline & Dose B & $1.0 \pm 0.17(6)$ & $0.08 \pm 0.02$ & (6) & $10.1 \pm 1.4 \quad(6)$ & $5.4 \pm 0.95$ \\
\hline & Dose C & $1.8 \pm 0.07(9)$ & $0.18 \pm 0.02$ & (9) & $14.2 \pm 1.0$ & $8.7 \pm 0.25$ \\
\hline \multirow[t]{3}{*}{$P$ value 11 p.m. vs. 8 a.m. } & Dose A & $\mathrm{NS}^{*}$ & NS & & NS & NS \\
\hline & Dose B & NS & NS & & $<0.05$ & NS \\
\hline & Dose $\mathrm{C}$ & $<0.001$ & $<0.001$ & & $<0.001$ & $<0.001$ \\
\hline \multicolumn{7}{|c|}{ Series II : plasma cortisol concentration maximal at 11 p.m. } \\
\hline HGH 8 a.m. & Dose $\mathrm{C}$ & $1.4 \pm 0.1$ & $0.17 \pm 0.01$ & (3) & $11.1 \pm 1.03$ & $8.9 \pm 0.27$ \\
\hline HGH 11 p.m. & Dose $\mathrm{C}$ & $0.7 \pm 0.06$ & $0.06 \pm 0.02$ & (3) & $6.1 \pm 1.3$ & $4.4 \pm 0.43$ \\
\hline$P$ value 11 p.m. vs. 8 a.m. & Dose C & $<0.005$ & $<0.005$ & & $<0.05$ & $<0.001$ \\
\hline
\end{tabular}

Values represent average $\pm \mathrm{SE}(n)$.

* NS signifies $P>0.05$.

Three mechanisms for the greater anabolic effect of $\mathrm{HGH}$ administered at bedtime can be visualized: $(a)$ The lesser nocturnal physical activity may facilitate the anabolic processes. (b) The adipokinetic action of $\mathrm{HGH}$, which plays a role in the overall anabolic effect, depends on fasting (30); $\mathrm{HGH}$ injected at bedtime will promote mobilization of free fatty acids during the fasting hours of the night, while this effect after matinal injection will be inhibited by the diurnal food intake (30). (c) The anabolic action of $\mathrm{HGH}$, which is opposed by cortisol $(25,26)$, may be greater after nocturnal injection because the hormone reaches its target tissues during a period when cortisol concentration in extracellular fluids is low.

That mechanism $(c)$ is at least partly responsible was shown by experiments of series II and III in hypophysectomized patients receiving exogenous cortisol. Whether $\mathrm{HGH}$ was administered at 8 a.m. or 11 p.m., its anabolic effect was enhanced by separating the administration of $\mathrm{HGH}$ and cortisol in time by 8-10 h, thereby reducing the plasma cortisol concentration to $<5 \mu \mathrm{g} / 100 \mathrm{ml}$ at the time of $\mathrm{HGH}$ injection.

These findings indicate that the anabolic effect of exogenous $\mathrm{HGH}$ is influenced by the plasma cortisol concentration at the time of $\mathrm{HGH}$ injection, but they do not rule out possible additional influences (mentioned above) by diurnal variations in food intake and physical activity.

We do not know to what extent these relationships in anabolic response during 7 days of $\mathrm{HGH}$ treatment can be extrapolated to growth response during months of treatment. Furthermore, we did not investigate other metabolic effects of $\mathrm{HGH}$, such as reduction in carbohydrate tolerance, decline in plasma amino acid and urea levels, and increase in plasma concentrations of insulin and free fatty acids. The indicators of response to $\mathrm{HGH}$ which were monitored, however, are those acute metabolic events most closely related to growth, viz. the deposition of $\mathrm{N}, \mathrm{P}$, and $\mathrm{K}$ in protoplasm. Therefore, it seems logical that the influences of timing of $\mathrm{HGH}$ and cortisol upon the anabolic response to the former, in short-term studies, may have their counterparts in linear growth response during chronic treatment. The present study thus suggests that the growth response to exogenous $\mathrm{HGH}$ by children with isolated $\mathrm{GH}$ deficiency will be greater if the hormone is injected at 11 p.m. than at 8 a.m., and in those children who also have $\mathrm{ACTH}$ deficiency, if the entire daily dose of cortisol is given at 7 a.m. Similarly, the present data suggest that any long-term anabolic effects of $\mathrm{HGH}$ on muscles of patients with limb-girdle dystrophy will be greater if the hormone is injected at 11 p.m. than at 8 a.m. The validity of these predictions, however, will need to be tested in appropriate long-term experiments.

The present study utilized only two periods of the day for administration of cortisol and HGH : 7-8 a.m. and 10-11 p.m. Possibly separation of the two hormones in time by a period smaller than 8-12 h, or some schedule of divided doses, may lead to further enhancement of the anabolic response to $\mathrm{HGH}$.

\section{ACKNOWLEDGMENTS}

This investigation was supported by U. S. Public Health Service Grants RR 00039 and HD 04485. 


\section{REFERENCES}

1. Rudman, D., S. B. Chyatte, J. H. Patterson, G. G. Gerron, I. O'Beirne, J. Barlow, P. Ahmann, A. Jordan, and R. C. Mosteller. 1971. Observations on the responsiveness of human subjects to human growth hormone. J. Clin. Invest. 50: 1941.

2. Rudman, D., S. B. Chyatte, J. H. Patterson, G. G. Gerron, I. O'Beirne, J. Barlow, A. Jordan, and J. S. Shavin. 1972. Metabolic effects of human growth hormone and of estrogens in boys with Duchenne muscular dystrophy. J. Clin. Invest. 51:1118.

3. Rudman, D., S. B. Chyatte, G. G. Gerron, I. O'Beirne, and J. Barlow. 1972. Hyper-responsiveness of patients with limb-girdle dystrophy to human growth hormone. J. Clin. Endocrinol. Metab. 35: 256.

4. Bergenstal, D. M., and M. B. Lipsett. 1960. Metabolic effects of human growth hormone and growth hormone of other species in man. J. Clin. Endocrinol. Metab. 20: 1427.

5. Henneman, P. H., A. P. Forbes, M. Moldawer, E. F. Dempsey, and E. L. Carroll. 1960. Effects of human growth hormone in man. J. Clin. Invest. 39: 1223.

6. Ikkos, D., R. Luft, and C. A. Gemzell. 1959. The effect of human growth hormone in man. Acta Endocrinol. 32: 341.

7. Prader, A., R. Illig, J. Szeky, and H. Wagner. 1964. The effect of human growth hormone in hypopituitary dwarfism. 1964. Arch. Dis. Child. 39: 535.

8. Brown, G. A., L. Stimmler, and J. G. Lines. 1967. Growth hormone-induced nitrogen retention in children of short stature. Arch. Dis. Child. 42: 239.

9. Soyka, L., A. Ziskind, and J. D. Crawford. 1964. Treatment of short stature in children and adolescents with human pituitary growth hormone (Raben). N. Engl. J. Med. $271: 754$.

10. Tanner, J. M., R. H. Whitehouse, P. C. R. Hughes, and F. P. Vince. 1971. Effect of human growth hormone treatment for 1 to 7 years on growth of 100 children, with growth hormone deficiency, low birthweight, inherited smallness, Turner's syndrome, and other complaints. Arch. Dis. Child. 46: 745.

11. Raben, M. S. 1958. Treatment of a pituitary dwarf with human growth hormone. J. Clin. Endocrinol. Metab. 18: 901 .

12. Sheppard, T. H., II, S. Waxman, N. Bernstein, and P. Ferrier. 1960. Human growth hormone. II. Further study of its effect on growth in dwarfism. J. Pediatr. 57: 363 .

13. Escamilla, R. F., J. J. Hutchings, W. C. Deamer, C. H. $\mathrm{Li}$, and P. H. Forsham. 1961. Long-term effects of human growth hormone $(\mathrm{Li})$ in pituitary dwarf. J. Clin. Endocrinol. Metab. $21: 721$.

14. Raben, M. S. 1962. Growth hormone. 2. Clinical use of growth hormone. N. Engl. J. Med. 266: 82.

15. Wright, J. C., J. A. Brasel, T. Aceto, Jr., J. W. Finkelstein, F. M. Kenny, J. S. Spaulding, and R. M. Blizzard. 1965. Studies with human growth hormone (HGH). An attempt to correlate metabolic response during shortterm administration with linear growth during prolonged therapy. Am. J. Med. $38: 499$.

16. Najjar, S., and R. M. Blizzard. 1966. Current concepts regarding human growth hormone (somatotropin). Pediatr. Clin. North Am. 13: 437.

17. Rozin, R., H. S. Soroff, J. Mooty, A. Ramirez, and M. Raben. 1968. Effects of human growth hormone on the metabolic balance and energy utilization following burns. Ann. N. Y. Acad. Sci. 150: 690.

18. Liljedahl, S. O., C. H. Gemzell, L. O. Rlantin, and G. Birke. 1961. Effect of human growth hormone in patients with severe burns. Acta Chir. Scand. 122: 1.

19. Ernesti, M., M. L. Mitchell, M. S. Raben, and Y. Gilboa. 1965. Control of hypoglycemia with diazoxide and human growth hormone. Lancet. 1: 628.

20. Mahon, W. A., M. L. Mitchell, J. Steinke, and M. S. Raben. 1962. Effect of human growth hormone on hypoglycemic states. N. Engl. J. Med. 267: 1179.

21. Glick, S. M., J. Roth, and E. T. Lonergan. 1964. Survival of endogenous human growth hormone in plasma. J. Clin. Endocrinol. Metab. $24: 501$.

22. Refetoff, S., and P. H. Sönksen. 1970. Disappearance rate of endogenous and exogenous human growth hormone in man. J. Clin. Endocrinol. Metab. 30: 386.

23. Parlow, A. F., A. E. Wilhelmi, and L. E. Reichert, Jr. 1965. Further studies in the fractionation of human pituitary glands. Endocrinology. 77: 1126.

24. Parker, D. C., J. F. Sassin, J. W. Mace, R. W. Gotlin, and L. G. Rossman. 1969. Human growth hormone release during sleep: electroencephalographic correlation. J. Clin. Endocrinol. Metab. 29: 871.

25. Soyka, L. F., and J. D. Crawford. 1965. Antagonism by cortisone of the linear growth induced in hypopituitary patients and hypophysectomized rats by human growth hormone. J. Clin. Endocrinol. Metab. 25: 469.

26. Morris, H. G., J. R. Jorgensen, H. Elrick, and R. E. Goldsmith. 1968. Metabolic effects of human growth hormone in corticosteroid-treated children. J. Clin. Invest. $47: 436$.

27. Hellman, L., F. Nakada. J. Curti. E. D. Weitzman, J. Kream, H. Roffwarg, S. Ellman, D. K. Fukushima, and T. F. Gallagher. 1970. Cortisol is secreted episodically by normal man. J. Clin. Endocrinol. Metab. 30: 411.

28. Bliss, E. L., A. A. Sandberg, D. H. Nelson, and K. Eik-Nes. 1953. The normal levels of 17-hydroxycorticoids in the peripheral blood of man. J. Clin. Invest. 32: 818.

29. Migeon, C. J., F. H. Tyler, J. P. Mahoney, A. A. Florentin, H. Castle, E. L. Bliss, and L. T. Samuels. 1956. The diurnal variation of plasma levels and urinary excretion of 17-hydroxycorticosteroids in normal subjects, night workers and blind subjects. J. Clin. Endocrinol. Metab. 16: 622 .

30. Raben, M. S., and C. H. Hollenberg. 1959. Effect of growth hormone on plasma fatty acids. J. Clin. Invest. $38: 484$.

31. Lilienfeld, A. M., M. Jacobs, and M. Willis. 1954. A study of the reproducibility of muscle testing and certain other aspects of muscle scoring. Physical Therapy $R e-$ view. 34: 279.

32. Swinyard, C. A., G. C. Deaver, and L. Greenspan. 1957. Gradients of functional ability of importance in rehabilitation of patients with progressive muscular and neuromuscular diseases. Arch. Phys. Med. Rehabil. 38: 574. 